\title{
Sport Ecology: Conceptualizing an Emerging Subdiscipline Within Sport Management
}

\author{
Brian P. McCullough \\ Seattle University
}

\author{
Madeleine Orr \\ University of Minnesota
}

\author{
Timothy Kellison \\ Georgia State University
}

\begin{abstract}
The relationship between sport and the natural environment is bidirectional and critical to the production of sport products, events, and experiences. Researchers have studied sport and the natural environment within the various subdisciplines of sport management. However, given the changing climate and mounting public concern for the environment, there is pressure to reconsider the relevance and significance of the natural environment, which is taken for granted in managerial contexts. Reflecting the importance of the natural environment, the robustness of the current literature, and the potential for the future, we propose a new subdiscipline of sport management called sport ecology. Thus, we proposed, in this paper, a definition for sport ecology, (re)introduced key concepts related to this subdiscipline (e.g., sustainability, green), and highlighted the leading research that serves as the foundation for sport ecology. We concluded with a discussion on the ways sport ecology can informand be informed by-other subdisciplines of sport management.
\end{abstract}

Keywords: climate, environment, sustainability, weather

The relationship between sport and the natural environment is bidirectional; that is, sport impacts the natural environment and is impacted by the natural environment. Since the 1990s, sport management scholars have predominantly explored the ways the sport industry impacts the natural environment. They have done so through the lenses of sport sustainability (Chard \& Mallen, 2012; Kellison \& Hong, 2015; Mallen, Adams, Stevens, \& Thompson, 2010), corporate social responsibility (Casper, Pfahl, \& McSherry, 2012; Inoue \& Kent, 2012a, 2012b; Trendafilova et al., 2014), and sport industry's influence on proenvironmental behaviors (Casper, McCullough, \& Pfahl, in press; Casper, Pfahl, \& McCullough, 2017; Kellison \& Kim, 2014; McCullough, 2013; Trail, 2016; Trail \& McCullough, in press). Recently, a new line of research has emerged, exploring the impacts of climate change on the sport industry (Dingle \& Stewart, 2018; Orr \& Inoue, 2019) and adaptation behaviors of athletes, organizations, and fans (Orr \& Schneider, 2018).

To date, the study of sport and the natural environment has been disjointed, brought together solely by literature reviews (Mallen, 2018; Mallen, Stevens, \& Adams, 2011; Trendafilova \& McCullough, 2018), academic texts (Casper \& Pfahl, 2015a; McCullough \& Kellison, 2018), or siloed lines of research. This lack of cohesion stands in contrast to other subdisciplines of sport management, such as sport marketing and sport tourism, that enjoy widespread acknowledgment of their value, dedicated coursework and labs, and recognition within and across academic communities. The lack of cohesion may be explained by insufficient research or interest or because the state of the environment was previously taken for granted (Orr \& Inoue, 2019). Regardless, given the present state of the planet and the dependency of sport on natural resources, combined with the potential for sport to curtail the

McCullough is with Seattle University, Seattle, WA, USA. Orr is with the University of Minnesota, Minneapolis, MN, USA. Kellison is with Georgia State University, Atlanta, GA, USA. McCullough (mccullob@seattleu.edu) is corresponding author. industry's environmental impact and inspire proenvironmental behavior (Kellison \& McCullough, 2018), it is imperative that this subdiscipline be organized to advance research and industry practice, especially considering the current climate change discourse in global society (Sengupta, 2019; United Nations Framework Convention on Climate Change, 2017).

In this paper, we advanced the name sport ecology to formalize the subdiscipline of study on sport, the natural environment, and the relationship between the two. The following sections are dedicated to (a) defining terminology relevant to sport ecology, (b) highlighting research that can be classified under the sport ecology subdiscipline, (c) identifying links to other subdisciplines of sport management and possible research questions at the intersections of subdisciplines, and (d) discussing the ongoing advances in the sport industry related to sport ecology. Following these discussions, we argued that sport ecology research is sufficiently robust and salient to warrant recognition as a distinct subdiscipline of the sport management academy.

\section{Defining Terminology Relevant to Sport Ecology}

\section{Sport Ecology}

Sport ecology is the study of sport, the natural environment, and the bidirectional relationship between the two. The selection of this term over alternatives, such as sport sustainability, is intentional and strategic. Sport is defined broadly and includes the sector and each of its parts: athletes, coaches, managers, fans, suppliers, and more. The study of ecology dates to the mid-17th century and refers to the study of organisms and their environments (Odum \& Barrett, 1971). Given the focus on study and science, and the natural environment, sport ecology was deemed more appropriate than sport sustainability or green sport as an overarching term for this academic subdiscipline, though the latter two are common parlance among industry professionals. 
Some studies have used the term sport sustainability or simply sustainability to denote research on sport and the natural environment (e.g., Bodie \& Jackson, 2018; Fyall \& Jago, 2010). However, the term sustainability has far broader applications than the natural environment or natural resources: it can refer to cultural, social, or economic sustainability (Griessler \& Littig, 2005). As such, using the term sport sustainability may blur the focus on the natural environment and may broach other existing and worthwhile subdisciplines, such as sport for development and sport sociology. Further and importantly, not all research in sport ecology is-or will be-about sustainability or environmentalism. Some research may simply explore relationships between sport experiences and the natural environment without consideration for the principles of sustainability. For instance, research on fan comfort and spending behaviors in various weather conditions would fall under sport ecology research, but have nothing to do with sustainability.

Similarly, within industry practice, marketing rhetoric has convoluted many terms in sport ecology. The use of terms such as green and sustainability are misunderstood because their definitions are often vague (i.e., green) and nondescript (i.e., sustainability). As such, organizations have broadly classified themselves as sustainable or green without much precision as to what that constitutes (Chen \& Chang, 2013; Delmas \& Cuerel Burbano, 2011). Thus, there is need for a new term and independent, well-defined concepts within the literature.

To its strength, sport ecology represents an extension of the rich scientific traditions of human ecology, which has been extended into several sector-specific academic disciplines, such as recreation ecology (Monz, Pickering, \& Hadwen, 2013), tourism ecology (David, 2011), and business ecology (Abe, Bassett, \& Dempsey, 2012). Each subdiscipline has promoted a common line of research and knowledge transfer (e.g., Harvard Business School—Business and Environment), advanced sector-specific knowledge (e.g., Sloan MIT-Business and the Environment), organized formal and informal associations (e.g., The International Ecotourism Society), received recognition from governmental agencies (U.S. Geological Society), and influenced industry performance as they relate to the natural environment (e.g., "We're Still in It" Campaign, United Nations General Assembly Tourism Resolutions). While ecologyfocused research in business management, tourism, and recreation academic disciplines are distinct from one another, so too is sport ecology from those respective fields' topical foci. In the following sections, we introduced key concepts related to human interaction with the natural environment, broadly and within a sport management context. These concepts support prior research that serves as the foundation for sport ecology as a subdiscipline.

\section{Environmentalism}

Environmentalism has a long and complicated history, with roots in indigenous tradition, various religious texts, natural sciences, and community organizing. Its progress has been slow, complicated, and nonlinear (Haq \& Paul, 2012; Rootes, 2014). Many environmentalists cite 18th-century romanticism as the start of environmentalism. At the time, emotion and love gained traction in social thought, rising to levels of widespread interest, similar to science and logic (Hinchman \& Hinchman, 2007; Pepper, 1999). Nature began to be conceived as not just something to be studied, understood, controlled, consumed, and improved, but as an innately beautiful, living, important entity of its own right (Hinchman \& Hinchman, 2007).

Modern environmentalism (the mainstream environmental movement of the 21 st century in the Western world) grew out of public concern for national parks and wilderness preservation in the early 20th-century United States (Pepper, 1999). However, early movements were born of calls to preserve and protect natural lands as a piece of shared heritage, not to be sold nor controlled by private interests. These calls align with various religious and cultural texts and traditions, including the Bible, the Qur'an, the Tripitaka, and many indigenous religions (Guha \& Allier, 2013). Throughout the 20th century, environmentalism has advanced in all parts of the world (Frank, Hironaka, \& Schofer, 2000).

The concept of environmentalism is predicated on the notion that humankind ought to live harmoniously with nature (Pepper, 1999). This premise has been supported with two core argumentsone grounded in ecocentrism, the other in anthropocentrism. Ecocentrism puts the focus on the importance and value of nature and posits that we should preserve and protect nature because of its innate value. Conversely, anthropocentrism puts humans at the center of the argument and suggests we are reliant on nature; thus, preserving nature is an exercise of self-preservation (Gagnon Thomson \& Barton, 1994). Regardless of philosophical orientation, environmentalists argue for the protection and preservation of nature and natural resources, now and in the future.

In a similar way, sport researchers have highlighted the necessity for the environment to be viewed as a stakeholder within the sport sector as a result of the anthropocentrism perspective (Sartore-Baldwin \& McCullough, 2018). Others posit that such power structures within sport are institutionalized structures that undermine vulnerable stakeholders, including the natural environment (Sartore-Baldwin, McCullough, \& Quatman-Yates, 2017). Sartore-Baldwin and McCullough (2018) called for stronger ecocentric leadership within the sport sector to address these imbalanced power structures and exploitation of the natural environment at the expense of future generations.

\section{Sustainability}

Around the same time modern environmentalism began picking up steam in the Western world (the second half of the 20th century), sustainability entered the global public lexicon. Despite having no clear definition and innumerable applications (Beatley, 1995; Grinstead, 2018), sustainability rapidly grew to become what is perhaps the most important buzzword in contemporary global policy. The notion of sustainability initially arose from philosophical and scientific discussions about limits to growth, pressures on the environment, and the role of humankind in nature. These topics have been of interest to the scientific community since the $1800 \mathrm{~s}$, but it was not until 1972 that the word sustainable was first used in the context of the future in A Blueprint for Survival (Goldsmith, 1972).

The most commonly applied definition of sustainability was inked in "Our Common Future," a report of the World Commission on Environment and Development, which defined sustainable development as development that "meets the needs of the present without compromising the ability of future generations to meet their own needs" (World Commission on Environment and Development, 1987 , p. 7). This definition implies a loose association between sustainability and the principle of prosperity in economics and carries a positive connotation.

Over time, sustainability has permeated nearly every academic domain, industry, and policy context. In sport management, sustainability has been applied to explain long-term economic prosperity (Fort, 2010; Lindsey, 2008), social welfare (Smith, 2009; Taks, 2013), environmental well-being (Fyall \& Jago, 2010; 
Mallen et al., 2011), and organizational longevity (Schubring \& Thiel, 2014; Svensson, 2017).

The term sustainability is oft-critiqued for a lack of a scientific foundation or formalized definition (Beatley, 1995; Grinstead, 2018), making it susceptible to misconception, which has threatened the legitimacy and utility of the term. It has become a buzzword, which is good in the sense that it is well known and generally understood, but bad because it risks being misused, overused, or improperly invoked (Grinstead, 2018), much like the accompanying term green.

\section{Green}

Green is an adjective typically invoked to describe an environmentally friendly or sustainable product, organization, behavior, or action. While it is generally viewed as positive (Griskevicius, Tybur, \& Van deb Burgh, 2010), the term green lacks formal definition and is therefore susceptible to misrepresentation, like the word sustainability. Green has been appropriated by marketers to promote their organizations, products, or services as good for the environment, without much consideration to the environmental impact, at times, of alternative ways of production (Banerjee, Gulas, \& Iyer, 2013; Schmuck, Matthes, \& Naderer, 2018). The term also misses the necessity of conveying the ongoing process of continual improvement of mitigating negative impacts on the natural environment as a result of production and consumption. Thus, greening was introduced as a way to convey the continuous efforts rather than seeing green as a final destination (Banerjee et al., 2013).

The sport management literature is similarly culpable of using the term green to represent sustainability in a nondescript way (Choi, 2016; Greenhalgh, LeCrom, \& Dwyer, 2015; McCullough $\&$ Kellison, 2016). The challenge with academics using such vague and nondescript terms is that we contribute and support, whether directly or indirectly, to slowing progress toward mitigating impacts as a result of advancing the narrative that "sustainable" or "green" organizations are the ends to the means. From this perspective, we miss other aspects, such as the impact of climate change on vulnerable populations and the necessary adaptations that result from those detrimental effects.

\section{Environmental Justice}

Environmental justice refers to the social movement surrounding such terms as environmental racism (e.g., Chavis \& Lee, 1987) and environmental inequality (Sze \& London, 2008). This movement represents the intersection of economic, social, political, and cultural disparities, and environmental issues. Environmental justice advocates view nature and its ecosystem services (i.e., features of the natural environment that afford humans the necessary resources to live, work, and play), as a "structuring agent in the production of power, hierarchies, human subjectivities, and political realities" (Mcincyte, Casper, \& Cole, 2009, p. 106).

It is well established that ecosystem services such as fresh air, green space, clean water, and access to safe outdoor leisure spaces are not equitably distributed (Daw, Brown, Rosendo, \& Pomeroy, 2011; Ernston, 2013). For instance, in North America, well-kept parks and green spaces are generally a feature of middle- and upper-class neighborhoods, relegating the poor to small and unkempt concrete spaces for play (Billaudreau et al., 2011; Rigolon \& Flor, 2014). The same is true for public school sporting facilities in rich and poor neighborhoods (Collins, 2003;
Lemon, 2006) and public sport facilities such as sport fields, public pools, and public basketball courts (McKenzie, Moody, Carlson, Lopez, \& Elder, 2013).

Another example of environmental justice issues in sport is the placement and construction of new stadia. When new stadia are built, they can produce environmental externalities in the form of pollution during construction, increased traffic causing poor air quality in adjoining neighborhoods, and degradation of existing green spaces (Collins \& Grineski, 2008; Sze, 2009). Typically, those who bear the brunt of these negative externalities are poor communities (e.g., displacement, pollution; Sze, 2009; Wallace, 2012). This is important, as it demonstrates how environmental injustices can be promulgated by efforts of the sport industry.

\section{Vulnerability, Climate Capacity, and Adaptation}

The concept of vulnerability originated in natural resource research, but researchers have expanded it to denote the degrees and points of weakness and exposure to threats in fields as diverse as ecology, public health, political science, and agriculture (Füssel, 2007). In sport management, the concept of vulnerability has been used to describe financial weakness (Cordery, Sim, \& Baskerville, 2013), shortcomings of performance regimes (Sam \& Macris, 2014), and issues relating to abuse and harassment of vulnerable populations (Kirby, Demers, \& Parent, 2008). Most recently, Orr and Inoue (2019) applied vulnerability to the concept of the natural environment and climate change as a potential risk to sport organizations. Used in this context, climate vulnerability refers to "the degree to which a system is susceptible to, and unable to cope with, adverse effects of climate change, including climate variability and extremes" (Stocker et al., 2001, p. 388). Examples of climate vulnerability as an issue include ski organizations facing low-snow winters or shortening seasons (Orr \& Schneider, 2018), a sport facility impacted by a natural disaster (Dingle \& Stewart, 2018), and a pond hockey tournament with an uncertain future (Fairley, Ruhanen, \& Lovegrove, 2015).

In the face of climate vulnerability, sport entities may already be prepared to respond and continue operations without disruptions or delays. Climate capacity is the capability of a person, organization, or industry to adjust to changes in the natural environment with minimal disruptions or additional costs (Orr \& Inoue, 2019). An example of a sport organization with high climate capacity would be an indoor sport facility, such as a basketball arena, in a region with few natural disasters and low projected changes in climate over the next 30-50 years. Where capacity is lacking, sport organizations can partake in the dynamic process of adapting to their new (or changing) environment.

Adaptation, in the context of sport ecology, is the process of making internal adjustments to accommodate environmental changes and variations. Adaptation can be intentional or unintentional and undertaken at any level: a person, a facility, an organization, an industry, a nation. Adaptation is a process-centric concept, and to adapt, the observational unit must have the sufficient capacity to carry out the necessary changes (e.g., going zero waste requires financial resources, human resources, infrastructural resources; Orr \& Inoue, 2019). As such, to adapt is to build climate capacity in those resource areas where resources are presently insufficient to meet the challenges of the changing environment. These concepts - vulnerability, climate capacity, and adaptationare becoming increasingly important as climate hazards present themselves to sport organizations on a more frequent or more 
severe basis (Dingle \& Stewart, 2018; Orr \& Inoue, 2019; Orr \& Schneider, 2018).

In summary, the reintroduction of these terms gives way to the researchers and their work that serve as the foundation that necessitates the formation of the sport ecology subdiscipline. In the section below, we have briefly summarized this body of literature, noting prior reviews conducted within the academy (Mallen, 2018; Mallen et al., 2011; Trendafilova \& McCullough, 2018). This summary will demonstrate the bidirectional relationship between sport and the natural environment.

\section{A Selection of Sport Ecology Research to 2019}

Beginning in the 2010s, the sport ecology literature has grown considerably. As evidence of this growth, several reviews have been produced to guide scholars on the scope and direction of the existing research. Mallen (2018) reviewed 53 articles published in sport-related journals between 2009 and 2015. Compared with a previous review of articles published between 1987 and 2008 (Mallen et al., 2011), she observed a $311 \%$ increase in the number of publications in sport-related journals in the more recent 7-year span. After organizing all articles into six themes, she noted the majority focused on introductory concepts of environmental sustainability and environmental activities in stakeholder disclosure relationships. A handful of studies related to environmental tracking, and none were published on the subjects of environmental operational countermeasures, inputs measurement, and outputs measurement. In a third review, Trendafilova and McCullough (2018) analyzed 84 articles on sport ecology published between 2007 and 2017 and found that the majority of articles could be categorized into one of three categories: management, spectator and fan behavior, and facilities management. Performance evaluation and social sustainability were also addressed, but less represented.

Textbooks and book chapters have provided syntheses of key sustainability concepts, while other review articles have discussed the future of sport ecology. For example, books have ranged from practice based (Pfahl, 2011; Savery \& Gilbert, 2011) to more specialized texts focusing on theory development, strategy, marketing, finance, law, ethics, facility operations, and event management (Casper \& Pfahl, 2015b; McCullough \& Kellison, 2018). Discussing the current momentum of sport-focused sustainability, Kellison and McCullough (2016) highlighted four trends underlying this trend, including growing public concern for the environment, a more comprehensive understanding of costs and benefits among sport managers, the formation of cross-functional and crosssector teams in sport organizations, and greater emphasis by the academy on developing specialists and research agendas.

Broadly, the academic literature on sport ecology has centered on either the environmental impact of sport or the environmental impact on sport (Orr \& Inoue, 2019). On the topic of sport's environmental impact, researchers have focused mainly on measuring environmental impact, reducing the impact of sporting events and infrastructure on the natural environment, or campaigning to use sport to catalyze positive environmental change (e.g., by increasing knowledge and promoting behavior change among fans). Conversely, studies of the impact of the environment on sport have considered how global issues like climate change may affect sport at all levels. A selection of these approaches is discussed in turn below to demonstrate the robustness of sport ecology research; however, an exhaustive review is necessary to identify what would be identified as sport ecology research.

\section{Environmental Impact of Sport}

To assess the environmental impact associated with spectator activity, Collins and Roberts (2018) outlined two different approaches-ecological footprint and environmental input-output analysis - and applied them to the FA Cup, Six Nations Rugby, and Tour de France. The environmental impact of spectatorship was similarly studied by Locke (2019), who found attendance at a Major League Baseball game had "a statistically significant but negligible impact on local air pollution" (p. 236). Interest in measuring the environmental impact of sport spectators has been extended to college football, where researchers have examined the effects of transportation (Triantafyllidis, Ries, \& Kaplanidou, 2018) and tailgating (Casper \& Bunds, 2018; Gillentine, 2018) on air quality.

A second area related to the environmental impact of sport has focused on the carbon footprint of sport participation, including among community-based ice hockey players in Ontario (Chard \& Mallen, 2012), varsity athletes at The University of British Columbia (Dolf \& Teehan, 2015), and skiers and snowboarders in Germany (Wicker, 2018). A broader study of adult sport participants in Germany by Wicker (2019) showed that participants in nature sports had larger carbon footprints than participants in team/racket sports. Furthermore, the environmental consciousness of athletes participating in individual sports significantly reduced their carbon emissions; the same was not true among participants in team or racket sports and nature sports. According to Wicker, this finding provided evidence of an environmental value-action gap, a paradox in which individuals with high levels of environmental consciousness do not necessarily act in proenvironmental ways.

Given the environmental costs associated with sport participation and major sporting events, some researchers have explored strategies to reduce sport's environmental impact. Some lines of research have focused on a top-down approach, in which major sporting leagues or governing bodies like the International Olympic Committee initiate sustainable action. Given the size and scope of the Olympic and Paralympic Games, much attention has been on the International Olympic Committee. Due in part to pressure from environmental activists (Cantelon \& Letters, 2000; Kim \& Chung, 2018), the International Olympic Committee has made environmental sustainability a primary component of the Olympic Movement (Lesjø \& Gulbrandsen, 2018; Ross \& Leopkey, 2017). As Kellison and Casper (2017) have written, however, even wellintentioned local organizing committees may struggle with fulfilling the promise of a positive environmental legacy, due to postevent budget reprioritization, the complexity of sustainable stadium design, and difficulty measuring environmental impact. Other top-down approaches have come in the form of legislative intervention mandating that sports venues comply with environmental statutes (though these regulations have been circumvented in the past; Geeraert, 2018; Porteshawver, 2018).

A second approach to examining sport's role in the environment has been a bottom-up perspective, in which individual teams promote sustainable behaviors without a mandate from a government, governing body, or league. Several leading organizations have demonstrated exceptional environmental stewardship through the sustainable designs of new stadia or eco-friendly retrofits of existing stadia (Kellison, 2015; Kellison \& Hong, 2015). In addition to the potential environmental and economic benefits from 
environmentally friendly venues, these facilities may serve as physical markers of an organization's commitment to the environment. Given the academy's emphasis on sport as a vehicle for positive social change, early adopters of sustainable facility designs have the potential to compel proenvironmentalism in the sport industry and among fans (Kellison, Trendafilova, \& McCullough, 2015). Despite the leadership of a few industry leaders in sport ecology, several factors have contributed to the relatively slow adoption of sustainable designs, including insufficient staff, limited funding, lack of knowledge about novel technologies, facility age, and the reluctance of ownership (Trendafilova, Kellison, \& Spearman, 2014).

Organizations that have actively promoted their environmentally friendly initiatives may be driven by the desire to attract new fans through community goodwill (Kellison \& Kim, 2014; Kellison \& Mondello, 2012); alternatively, they may endeavor to inspire positive environmental change in existing fans' match day and at-home behaviors. Casper, Pfahl, and McCullough (2014, 2017) argued that fans have come to expect sport organizations' engagement in proenvironmental initiatives. Furthermore, by educating fans about sustainable behaviors like waste reduction and water conservation, the organizations may positively influence fans' environmental actions. Because of the potential influence of sport on consumers' environmental behaviors, it is increasingly important to find out what methods best engage fans (Trail \& McCullough, 2018). This information has become particularly important for organizations with robust waste management programs, and researchers have examined best practices for promoting recycling behaviors among sport consumers, ranging from youth baseball spectators (McCullough \& Cunningham, 2011) to tailgaters (Martin, Ross, \& Irwin, 2015) to attendees of big time sport (McCullough, 2013).

For organizations not actively involved in proenvironmental programming, several factors may contribute to their inaction. For instance, in their study of university athletic departments, Casper et al. (2012) noted that, although environmental concern was high among athletic administrators, there was little action being taken by the departments as a whole, again underscoring the value-action gap discussed previously by Wicker (2018, 2019). Reasons for athletic departments' reluctance included a lack of communication between the athletic department and the broader university, perceived costs of environmental programming, and a lack of knowledge about sustainability initiatives. At the National Collegiate Athletic Association Division III level, Casper and Pfahl (2015a) identified three critical barriers to the implementation of proenvironmental initiatives: a lack of funding to support efforts, a need for additional staff that could specialize in sustainability initiatives, and a desire for information gathering and further planning. In response to these concerns, organizations across all levels of sport have begun creating so-called green teams, cross-sector social partnerships comprising several different specializations, with the aim of identifying and removing barriers in order to promote sport ecology (McCullough, Kellison, \& Wendling, 2018; Pfahl, Casper, Trendafilova, McCullough, \& Nguyen, 2015).

\section{Environmental Impact on Sport}

An emerging but important line of research has focused on the effects of climate change on sport. As Orr and Inoue (2019) discussed, despite the threat of lower revenues, damage to facilities, event cancelations, and declining interest in sport, "most sport organizations remain ill-equipped to proactively assess and manage the risks of the climate challenge" (p. 2). For facility operators and event managers, the warming planet will have significant implications related to water, energy, and waste (Dingle \& Stewart, 2018; Phillips \& Turner, 2014). Additionally, the declining quality of the natural environment may result in a lower usage of public parks and other community spaces of play (Kellison, Bunds, Casper, \& Newman, 2017).

In several recent studies, researchers have analyzed the effects of existing environmental conditions on the delivery of professional sport. For example, Watanabe, Yan, Soebbing, and Fu (2019) explored the impact of air quality on attendance in the Chinese Super League (soccer) and found that the presence of air pollution did not impact consumers' consumption habits. They concluded that, while there would be no apparent economic incentive to do so, "establishing league-wide policies and measures that take air pollution and consumer health into consideration is vital for the functioning of the [league], as well as the support from wider publics" (p. 10). In a second study, Archsmith, Heyes, and Saberian (2018) investigated the role air pollution played in the performance of professional baseball umpires and concluded, "Air quality clearly impacts [Major League Baseball] umpires” (p. 860).

Finally, because of the effects of climate change and extreme weather, sport managers are already anticipating profound changes to how sport is delivered. For instance, in historically cold-weather communities, rising temperatures have produced unsafe snow conditions and unstable ice surfaces, forcing sport managers to consider alternative events for pond hockey (Fairley et al., 2015) and cross-country skiing (Orr \& Schneider, 2018). On a larger scale, DeChano-Cook and Shelley (2018) estimated the likelihood that former host cities could host the Olympic and Paralympic Games in 2100 , using predictions of a $1.8-5.4{ }^{\circ} \mathrm{F}\left(1-4{ }^{\circ} \mathrm{C}\right)$ increase in temperature and 1-3.9 ft. (0.3-1.2 m) sea-level rise (based on projections from the Intergovernmental Panel on Climate Change and National Climate Assessment). They concluded "many of the cities that once hosted Summer and Winter Olympic Games are no longer suitable venues for future competitions because of warmer winters, hotter summers, and/or coastal locations." They added, "As a result, the number of potential venues for future Olympic Games continues to decrease" (p. 76). Each challenge presented by climate change will necessitate strategic solutions, many of which will require interdisciplinary collaboration. Sport marketing, sport psychology, communication, and facility management are some of the subdisciplines of sport from which theory, frameworks, and innovative solution are likely to be drawn.

\section{Support Between Sport Ecology and Other Sport Management Subdisciplines}

The subdisciplines within sport management support each other through intra- and interdisciplinary research. The same is true with sport ecology and other subdisciplines within sport management. Sport ecology should influence and be influenced by the various subdisciplines, like marketing, psychology, and communication, among others. For example, a marketing campaign can focus on influencing consumer behaviors, but campaigns will vary based on the intended behavior (e.g., buying tickets vs. buying carbon offsets). Or similarly, understanding tailgater behaviors can be leveraged to increase zero-waste efforts among this population (Gillentine, 2018; Martin et al., 2015) or the impact that air pollution can have on the health of tailgaters (Casper \& Bunds, 2018). In the sections below, we have highlighted some of these 
subdisciplines and the research that serves as the foundational aspects that inform sport ecology.

\section{Organizational Behavior}

Researchers have explored ways to understand and explain the motives of sport organizations to protect the natural environment through their organizational operations and internal decisionmaking processes (Babiak \& Trendafilova, 2011; McCullough \& Cunningham, 2010). McCullough and Cunningham explained the pressures that would serve as an impetus for sport organizations to implement environmentally responsible practices. They suggested that engaging in such environmentally responsible organizational behaviors would have positive results, including cost savings, competitive advantages for early adopters, increased goodwill perceptions, and increased fan identification, all of which have been supported in subsequent empirical research. McCullough and Cunningham posited that the speed at which the organization would respond would be moderated by upper management's support of such efforts.

Similarly, Babiak and Trendafilova (2011) also used institutional theory to understand the motives of sport practitioners to adopt ecological management practices. Their basis of inquiry leveraged the premise that organizations will seek competitive advantages by differentiating themselves through corporate social responsibility (CSR) initiatives, or, as an organization may deem such efforts, "green management practices." They found that sport practitioners were likely to use green management practices strategically to boost their organizations' legitimacy among stakeholder groups to insulate the organization from criticism by creating positive public perception by way of responsible business practices. Similar to those findings, marketing research on environmental sustainability has been used to further the strategic research for adopting, integrating, and leveraging sport organization's ecological efforts (Chard, Mallen, \& Bradish, 2012).

\section{Marketing}

Babiak and Wolfe (2009) explored the marketing of the various CSR efforts associated with Super Bowl XL in Detroit. They examined the influence these efforts had on enhancing the National Football League's brand and image, common goals for CSR initiatives. Similarly, Inoue and Kent (2012a, 2012b) published two articles examining the capacity of sport organizations to be conduits of sustainability messaging to promote proenvironmental behaviors among fans. Their work added to the body of knowledge that sport organizations can be leveraged to promote sustainability messages and influence consumers' sustainability behaviors. Specifically, they found that fans need to view a sport organization with a certain degree of environmental credibility in order to receive the organization's sustainability behavior message (Inoue \& Kent, 2012a). Furthermore, Inoue and Kent found that internalizing the environmental message from the team significantly influenced fans' intentions to support the team's initiative and their intention to engage in proenvironmental behaviors at home.

Casper et al. (2014, 2017, in press) built on Inoue and Kent's (2012a, 2012b) work, exploring the influence a sport organization can have through its sustainability campaigns to influence sport fan behaviors at events and at home. They introduced the concept "ascription of responsibility" (Casper et al., 2014) and discussed its influence on fans' environmental values to messages and consequential behavioral intentions. Casper et al.'s most notable contribution to this space was to demonstrate that a sport organization's commitment to reducing its impact on the natural environment was favored by sport fans. In fact, they found that lower identified fans felt a deeper connection to the team because of the team's apparent concern for the natural environment.

\section{Psychology}

More recent work by Trail et al. (Trail, 2016; Trail \& McCullough, 2018 , in press) has built upon the previous findings of Inoue and Kent (2012a, 2012b), Casper et al. (2014, 2017, in press), and McCullough et al. (McCullough, 2013; McCullough \& Cunningham, 2011). Trail and McCullough (2018) adapted his Sport Consumer Behavior Model to assess the sustainability campaigns of sport organizations and events. Previously, the work by Inoue, Casper, and McCullough focused on assessing campaigns post hoc rather than evaluating how the campaign and messaging could be optimized to positively influence sustainable behaviors. Trail combined the use of a variety of behavioral theories from various academic disciplines (for a summary, see Trail \& McCullough, in press). Trail and McCullough's findings supported prior research that sport organizations and events can influence sustainable behaviors at events and at home.

Additionally, their research built upon McCullough's (2013) prior work to understand the influence of needs, values, internal constraints, and points of attachment on attitudes toward a specific sustainability campaign. Then, they determined the influence of attitudes, external constraints, and past behaviors on behavioral intentions. Ultimately, through their sport sustainability campaign evaluation model, sport organizations can apply market research to understand the segments of their stakeholders to properly understand the needs, values, attitudes, motivations, and constraints of possible market segments to appropriately craft campaigns to influence sustainable behaviors, much like a sales marketing campaign would — rather, in this instance, sport consumer behavior research is being used to promote sustainable and responsible behavior, and not necessarily consumerism.

\section{Communication}

Research in the parent disciplines of communication studies and policy studies consistently shows that many are not aware of - or interested in - the problem of climate change (Eisenack et al., 2014; Lee, Markowitz, Howe, Yo, \& Leiserowitz, 2015). Despite this lack of awareness and interest, scientists and innovators have developed solutions to the climate crisis that are ready for implementation, if only people were aware (e.g., Van Lange, Joireman, $\&$ Milinski, 2018). For this reason, public engagement (or, in the sport industry, fan engagement and sport communication) can be considered the next frontier of sustainability work. However, communicating about climate change and sustainability is challenging when the topic is politically charged (Fisher, Waggle, \& Leifeld, 2013; McCright \& Dunlap, 2011), the science is complicated, and the scope of the problem is oft perceived as overwhelming (Wolf \& Moser, 2011). Given these challenges, several important research agendas exist at the intersection of sport ecology and sport communication, including understanding (a) what terminology is most effective in communicating about climate change and sustainability in a sport setting; (b) how to distill the climate problem into manageable pieces of information that are simple, yet convey urgency; and (c) how to leverage existing sport communication channels to engage fans in the climate crisis. 


\section{Facility and Event Management}

Sport event managers began engaging in environmental sustainability initiatives in the mid-20th century, due in large part to pressure from environmentalists (Del Fiacco \& Orr, 2019). Case (2013) and Quinn (2013) elaborated on the contemporary history of sustainability in the sport event industry by reviewing the first set of environmental standards, namely, the United Nations Environmental Program's policies, of which they posited "many of them would appear to have had little impact directly on the event industry. However, the industry and its supply chain are affected by them" (Case, 2013, p. 115). For example, the United Nations's policies require suppliers to comply with a range of new local, regional, and national laws that were enacted to reduce pollution, such as noise restrictions that require events to acquire pollution permits and limits on the types of chemicals that could be used to produce certain special effects for live shows (Case, 2013). Over time, standards for the event industry have emerged at the national level in both Canada (with the Canadian Standards Association) and the United Kingdom (the BS8901; Case, 2013, Quinn, 2013).

The most recent advance in sport event and facility sustainability policy is the United Nations's Sports for Climate Action Framework (United Nations Framework Convention on Climate Change, 2017). However, despite the existence of standards, policies, and guidelines for achieving sustainability in sport events and facilities, a common critique is limited to monitoring and reporting (Dolf \& Teehan, 2015; McCullough, Pfahl, \& Nguyen, 2016). The lack of monitoring hampers the potential to assess the overall progress of the industry and to measure individual improvements, leaving room for an overexaggeration of the efforts made (i.e., greenwashing). Furthermore, barriers to implementing sustainable building features and infrastructure remain, including low buy-in from management and high initial costs (Kellison, 2015; Kellison \& Hong, 2015). Nonetheless, there is sufficient evidence to suggest sustainability is advancing (albeit slowly) in the sport facilities and events space.

\section{Law and Governance}

In the past decade, less than one quarter of all new professional arenas and stadia in North America were constructed with comprehensive sustainable designs (Center for Sport and Urban Policy, 2019). Some scholars have contended that local or statewide mandates would be the most effective vehicle for promoting green facility designs: "Rather than convincing team owners and sport managers that instituting environmental initiatives would be economically viable or is morally imperative, legislative intervention would provide a clear path to normalizing sustainability in sport" (Kellison \& McCullough, 2018, p. 453). One such form of legislation, state environmental policy acts, requires that projects undergo a detailed environmental review prior to receiving state approval (e.g., in the form of bond or permit issuances; Porteshawver, 2010). However, state environmental policy acts may be sidestepped in order to fast-track the approval and construction processes: "In theory, environmental review of arena and stadium plans prior to construction should identify and require that facilities 'go green,' but oftentimes stadia are exempt from meaningful review because of legislative action" (Porteshawver, 2018, p. 390). It has become increasingly commonplace for sports organizations to circumvent state environmental policy acts in California (Bodie \& Jackson, 2018; McLeod \& Holden, 2017, 2018), where environmental review requirements have recently been amended for projects associated with the Los Angeles Rams (Associated Press, 2015), Los Angeles
Angels (Shaikin, 2016), Oakland A's (DeBolt, 2017), and Sacramento Kings (Dillon \& Fenno, 2017).

Future research may expand the application of sport ecology to environmental law in the context of public sports facility negotiations. Continued inquiry on this topic may explain the arguments that position environmental and economic benefits at odds with one another. In doing so, researchers may provide insight on how legislators aim to support public sports facility developments while tempering concern over the environmental impact of such support. Furthermore, future studies may explore the fulfillment or abandonment of environmental policies surrounding sporting events, mega-events (e.g., FIFA World Cup, Olympic and Paralympic Games), and the construction standards of college athletic facilities compared to typical campus buildings (e.g., Leadership in Energy and Environmental Design Silver certification minimum), as well as the justifications for these policy and managerial decisions.

\section{Finance and Economics}

The broader sport management academy has expanded in the important area of financial and economic research (Sloane, 2006). Specific to sport ecology, researchers have applied economic research methods and metadata to understand the link between air pollution and game attendance, including the influence of local air pollution on game attendance (Watanabe et al., 2019) and vice versa (Locke, 2019). Additional studies have considered the effect of air pollution on athlete performance (El Helou et al., 2012; Lippi, Guidi, \& Maffuli, 2008) and even umpire performance (Archsmith et al., 2018). Further inquiry is needed to examine the environmental costs (i.e., externalities) of environmental impacts associated with sport (McCullough, Orr, \& Watanabe, in press). These environmental externalities ignore the true costs associated with hosting events that impact the local community and even vulnerable populations, as mentioned previous in the environmental justice section. In this vein, more research is necessary to identify the financial and economic implications of the environmental impact of individual events/ teams (e.g., facility operations), leagues (e.g., air travel), the broader sport industry (National Hockey League, 2014), and the subsequent environmental initiatives (e.g., return on investment). Such research studies can further examine the willingness to pay a carbon offsetting ticket fee (Drayer, Kunkel, \& Greenhalgh, 2016) or the receptivity to building such a fee into the base price of the ticket, like Union of European Football Associations (UEFA) has done (Campelli, 2018).

\section{Advocacy and Public Relations}

A fan's points of attachment with a team, city, stadium, community, or athlete can be used as a way to deliver an environmental message or behavioral prompt to an individual, a premise supported by McCullough and Kellison (2016) and the empirical findings of Trail and McCullough (in press). Lee and Cunningham (2019) examined the factors that led to social justice advocacy within the sport sector. These authors found that, consistent with Moeschberger, Ordonez, Shankar, and Raney's (2006) model for awareness and engagement, these social justice activists had direct experience with injustice. Similarly, athletes can be social justice activists for nature (Sartore-Baldwin \& McCullough, 2018). Given that athletes of outdoor sports engage directly with natural elements on a daily basis, they become direct witnesses and can fall victim to adverse environmental conditions and biodiversity losses. For 
instance, skiers experiencing shorter seasons are acutely aware of shifting seasonality due to climate change, and surfers are encountering ocean plastics on a regular basis, which may lead to increased awareness and interest in pollution control and ocean protection. Brymer, Downey, and Gray (2009) found that a direct connection with nature increased an individual's (i.e., athlete, sport participant, outdoor recreationist) "desire to care for the natural world" (p. 193) and thereby increased his or her attitude toward environmental preservation. These athletes can thereby serve as a proper platform to advocate for the environment.

\section{Industry Perspectives and Abundance of Research Subjects}

Sport relies on conditions of the natural environment and resources derived from the natural environment to be tenable (Orr \& Inoue, 2019). For instance, skiing requires snow, skating requires ice, and aquatic sports require water. It is therefore unsurprising that sport managers are aware of the conditions of the natural environment, as the management of land and natural resources are integral to managing sport and its supply chains (Dingle \& Stewart, 2018; Orr \& Inoue, 2019). To this end, there are professional training programs, including university coursework, dedicated to such topics as turf management, surf management, mountain and snow maintenance, and trail management. Furthermore, organizations are increasingly investing in weather radar technology to monitor storm activity, temperature patterns, and natural disasters like wildfires and tropical cyclones. Evidently, there is awareness and interest in the interconnectedness of sport and the natural environment, and research in this area could offer fruitful insight into practical challenges of operating sport.

In North America and Europe, the most significant advances in this sport ecology space have come in facility and event management: many facilities are implementing sustainable building improvements or construction principles, such as energy-saving lighting and low-flow faucets (Gibson, Lloyd, Bain, \& Hottel, 2008). It is becoming common for new sport facilities to seek and attain Leadership in Energy and Environmental Design designation or its international variants (Mallen et al., 2010). Given the demonstrated interest in implementing sustainable solutions, it is imperative that the academy continues to explore motivations, barriers, opportunities, and costs of such sustainability options to guide best practice.

The sport industry has several well-established and burgeoning organizations and associations dedicated to advancing the industry's commitments to sustainability, such as the Green Sports Alliance (North America and Japan), the British Association for Sustainable Sport (United Kingdom), and the Sports Environment Alliance (Australia). However, Trendafilova and McCullough (2018) noted in their research that there is a disconnect between academics and practitioners within this space. That is, unlike other industries, practitioners are not leveraging the vast knowledge and assistance in advancing the sport ecology movement, as do other industries. Despite this disconnect, these organizations are the conduit to influence and direct industry attention to various initiatives and the subsequent action required to reduce the sector's impact on the natural environment as a whole, but more specifically, among individual sport organizations and clubs.

Academics can lend their expertise to enhance and advance industry climate action efforts through a concerted effort and research within the sport ecology subdiscipline (McCullough \&
Kellison, in press). This concerted effort between practitioners and academics can leverage the specific discipline training of academics to identify and resolve natural and social phenomena concerning the interaction between the natural environment and sport or the consequences of that interaction. As a result, academics operating under the lens of the sport ecology subdiscipline can ensure more responsible management within the business sector pertinent to our academic discipline.

\section{Conclusion}

Establishing sport ecology as a subdiscipline of sport management carries several benefits. First, this designation will generate more awareness among academics about this research area, which leads to more opportunities to expand research agendas and draw connections between researchers' existing work and future project. Second, recognition of sport ecology as a subdiscipline facilitates the development of coursework to proactively support the education of future professionals working in this space (Mercado \& Grady, 2017). A third philosophical benefit is the formal recognition of the natural environment's influence and role in sport management and sport participation, and the importance of the natural environment as a passive stakeholder in the sport sector. An overarching benefit is the positive influence on industry practice through more purposeful research to inform sport practitioners and the enhanced education of current and future sport managers to be more apt to acknowledge and balance the relationship between sport and the natural environment.

In closing, sport ecology research is not new; it has been ongoing since the mid-20th century. Only now are we beginning to appreciate the importance and volume of this work and to attribute a name to this body of work that examines sport, the natural environment, and the relationship between the two. NGO organizations have called for all entities to address the biggest global challenge of our generation-climate change. Our industry and academic discipline are not excused from this call. Building on the efforts of other researchers in this space-Casper, Collins, Mallen, Pfahl, Trendafilova, Dingle, among others - research in this area has reached a critical mass that merits more attentive consideration as a new subdiscipline of sport management, in the same way sport tourism, sport event management, and sport marketing have previously been formally or informally established as subdisciplines of sport management.

The climate crisis and unpredictable nature of environmental change make it necessary to collate and organize the natural environment research into a subdiscipline within our field, and quickly. A subdiscipline on sport ecology offers cohesion and clarity to this line of research and contributes meaningfully to industry practice.

\section{References}

Abe, J.M., Bassett, D.A., \& Dempsey, P.E. (2012). Business ecology: Giving your organization the natural edge. London, UK: Routledge.

Archsmith, J., Heyes, A., \& Saberian, S. (2018). Air quality and error quantity: Pollution and performance in a high-skilled, quality-focused occupation. Journal of the Association of Environmental and Resource Economists, 5(4), 827-863. doi:10.1086/698728

Associated Press. (2015, February 25). Inglewood approves stadium plans. $E S P N$. Retrieved from http://www.espn.com/los-angeles/nfl/story/_ id/12378821/inglewood-city-council-oks-fast-tracking-st-louis-ramsbacked-nfl-stadium 
Babiak, K., \& Trendafilova, S. (2011). CSR and environmental responsibility: Motives and pressures to adopt green management practices. Corporate Social Responsibility and Environmental Management, 18(1), 11-24. doi:10.1002/csr.229

Babiak, K., \& Wolfe, R. (2009). Determinants of corporate social responsibility in professional sport: Internal and external factors. Journal of Sport Management, 23(6), 717-742. doi:10.1123/jsm.23.6.717

Banerjee, D., Gulas, J., \& Iyer, E. (2013). Shades of green: A multidimensional analysis of environmental advertising. Journal of Advertising, 24(2), 21-31. doi:10.1080/00913367.1995.10673473

Beatley, T. (1995). The many meanings of sustainability: Introduction to a special issue of JPL. Journal of Planning, 9, 339-342.

Billaudreau, N., Oppert, J.-M., Simon, C., Charreire, H., Casey, R., Salze, P., ... Chaix, B. (2011). Investigating disparities in spatial accessibility to and characteristics of sport facilities: Direction, strength, and spatial scale of associations with area income. Health \& Place, 17(1), 114-121.

Bodie, M.T., \& Jackson, L.D. (2018). Laws and norms in sustainability developments in the major American sports leagues. In B.P. McCullough \& T.B. Kellison (Eds.), Routledge handbook of sport and the environment (pp. 418-428). New York, NY: Routledge.

Brymer, E., Downey, G.J., \& Gray, T.L. (2009). Extreme sports as a precursor to environmental sustainability. Journal of Sport \& Tourism, 14(2-3), 193-204. doi:10.1080/14775080902965223

Campelli, M. (2018, August 15). Sport and carbon offsetting: A complex and growing relationship [Blog post]. The Sport Sustainability Journal. Retrieved from https://sportsustainabilityjournal.com/analysis/ sport-and-carbon-offsetting-a-complex-and-growing-relationship/

Cantelon, H., \& Letters, M. (2000). The making of the IOC environmental policy as the third dimension of the Olympic movement. International Review for the Sociology of Sport, 35(3), 294-308. doi:10. $1177 / 101269000035003004$

Case, R. (2013). Events and the environment. New York, NY: Routledge.

Casper, J., McCullough, B.P., \& Pfahl, M.E. (in press). Examining environmental fan engagement initiatives through values and norms with intercollegiate sport fans. Sport Management Review, 1-37. doi:10.1016/j.smr.2019.03.005

Casper, J., Pfahl, M., \& McSherry, M. (2012). Athletics department awareness and action regarding the environment: A study of NCAA athletics department sustainability practices. Journal of Sport Management, 26(1), 11-29. doi:10.1123/jsm.26.1.11

Casper, J.M., \& Bunds, K.S. (2018). Tailgating and air quality. In B.P. McCullough \& T.B. Kellison (Eds.), Routledge handbook of sport and the environment (pp. 291-300). London, UK: Routledge.

Casper, J.M., \& Pfahl, M.E. (2015a). Environmental sustainability practices in U.S. NCAA Division III athletics departments. International Journal of Event Management Research, 10, 12-36.

Casper, J.M., \& Pfahl, M.E. (2015b). Sport management and the natural environment: Theory and practice. London, UK/New York, NY: Routledge.

Casper, J.M., Pfahl, M.E., \& McCullough, B.P. (2014). Intercollegiate sport and the environment: Examining fan engagement based on athletics department sustainability efforts. Journal of Issues in Intercollegiate Athletics, 7, 65-91.

Casper, J.M., Pfahl, M.E., \& McCullough, B.P. (2017). Is going green worth it? Assessing fan engagement and perceptions of athletic department environmental efforts. Journal of Applied Sport Management, 9(1), 106-134. doi:10.18666/JASM-2017-V9-I1-7690

Center for Sport and Urban Policy. (2019). Greentrack. Retrieved from http://www.stadiatrack.org/green

Chard, C., \& Mallen, C. (2012). Examining the linkages between automobile use and carbon impacts of community-based ice hockey.
Sport Management Review, 15(4), 476-484. doi:10.1016/j.smr.2012. 02.002

Chard, C., Mallen, C., \& Bradish, C.L. (2012). The responsibilities of Olympic sponsors? BP and the London 2012 Olympic Games. Case Studies in Sport Management, 2(1), 10-16. doi:10.1123/cssm.2.1.10

Chavis, B., Jr., \& Lee, C. (1987). Toxic wastes and race in the United States: A national report on the racial and socio-economic characteristics of communities with hazardous waste sites. New York, NY: United Church of Christ Commission for Racial Justice.

Chen, Y., \& Chang, H. (2013). Greenwash and green trust: The mediation effects of green consumer confusion and green perceived risk. Journal of Business Ethics, 114(3), 489-500. doi:10.1007/s10551012-1360-0

Choi, J.-S.A. (2016). Going green in baseball-A case study of the SK Wyverns. International Journal of Sports Marketing and Sponsorship, 17(4), 368-379. doi:10.1108/IJSMS-11-2016-022

Collins, A., \& Roberts, A. (2018). Assessing the environmental impact of economic activity surrounding major sports events. In B.P. McCullough \& T.B. Kellison (Eds.), Routledge handbook of sport and the environment (pp. 207-219). London, UK: Routledge.

Collins, M.F. (2003). Social exclusion from sport and leisure. In B. Houlihan (Ed.), Sport and society: A student introduction (pp. 77105). London, UK: Sage Publications.

Collins, T.W., \& Grineski, S.E. (2008). Unequal impacts of downtown redevelopment: The case of stadium building in Phoenix, AZ. Journal of Poverty, 11(1), 23-54. doi:10.1300/J134v11n01_02

Cordery, C.J., Sim, D., \& Baskerville, R.F. (2013). Three models, one goal: Assessing financial vulnerability in New Zealand amateur sports. Sport Management Review, 16(2), 186-199. doi:10.1016/j. smr.2012.08.002

David, L. (2011). Tourism ecology: Towards the responsible, sustainable tourism future. Worldwide Hospitality and Tourism Themes, 3, 210-216.

Daw, T., Brown, K., Rosendo, S., \& Pomeroy, R. (2011). Applying the ecosystem services concept to poverty alleviation: The need to disaggregate human well-being. Environmental Conservation, 38(4), 370-379. doi:10.1017/S0376892911000506

DeBolt, D. (2017, October 7). A's stadium: Environmental questions remain at Peralta site. Mercury News. Retrieved from https://www. mercurynews.com/2017/10/07/as-stadium-environmental-questionsremain-at-peralta-site/

DeChano-Cook, L.M., \& Shelley, F.M. (2018). Climate change and the future of international events: A case of the Olympic and Paralympic Games. In B.P. McCullough \& T.B. Kellison (Eds.), Routledge handbook of sport and the environment (pp. 66-78). London, UK: Routledge.

Del Fiacco, A., \& Orr, M. (2019). A review and synthesis of environmentalism within the Olympic Movement. International Journal of Event and Festival Management, 10(1), 67-80. doi:10.1108/IJEFM-052018-0038

Delmas, M., \& Cuerel Burbano, V. (2011). The drivers of greenwashing. California Management Review, 54(1), 3-38. doi:10.1525/cmr.2011. 54.1.64

Dillon, L., \& Fenno, N. (2017, August 23). Backers of a new Clippers arena in Inglewood push a last-minute plan in Sacramento. Los Angeles Times. Retrieved from http://www.latimes.com/politics/ la-pol-ca-inglewood-arena-legislative-exemption-20170823-story. html

Dingle, G.W., \& Stewart, B. (2018). Playing the climate game: climate change impacts, resilience and adaptation in the climate-dependent sport sector. Managing Sport and Leisure, 23(4-6), 293-314. doi:10. 1080/23750472.2018.1527715 
Dolf, M., \& Teehan, P. (2015). Reducing the carbon footprint of spectator and team travel at the University of British Columbia's varsity sports events. Sport Management Review, 18(2), 244-255. doi:10.1016/j. smr.2014.06.003

Drayer, J., Kunkel, T., \& Greenhalgh, G.P. (2016, September 7-10). Profiting from price partitioning in professional sport. Paper presented at the 24th European Association for Sport Management Conference, Warsaw, Poland.

Eisenack, K., Moser, S.C., Hoffmann, E., Klein, R.J.T., Oberlack, C., Pechan, A., ... Termeer, C.J.A.M. (2014). Explaining and overcoming barriers to climate change adaptation. Nature Climate Change, 4(10), 867-872. doi:10.1038/nclimate2350

El Helou, N., Tafflet, M., Berthelot, G., Tolaini, J., Marc, A., Guillaume, M., ... Toussaint, J.F. (2012). Impact of environmental parameters on marathon running performance. PLoS One, 7(5), e37407. PubMed ID: 22649525 doi:10.1371/journal.pone.0037407

Ernston, H. (2013). The social production of ecosystem services: A framework for studying environmental justice and ecological complexity in urbanized landscapes. Landscape and Urban Planning, 109(1), 7-17.

Fairley, S., Ruhanen, L., \& Lovegrove, H. (2015). On frozen ponds: The impact of climate change on hosting pond hockey tournaments. Sport Management Review, 18(4), 618-626. doi:10.1016/j.smr.2015.03.001

Fisher, D.R., Waggle, J., \& Leifeld, P. (2013). Where does political polarization come from? Locating polarization within the US climate change debate. American Behavioral Scientist, 57(1), 70-92. doi:10. $1177 / 0002764212463360$

Fort, R. (2010). An economic look at the sustainability of FBS athletic departments. Journal of Intercollegiate Sport, 3(1), 3-21. doi:10. $1123 /$ jis.3.1.3

Frank, D.J., Hironaka, A., \& Schofer, E. (2000). Environmentalism as a global institution: Reply to Buttel. American Sociological Review, 65(1), 122-127. doi:10.2307/2657293

Füssel, H.M. (2007). Adaptation planning for climate change: Concepts, assessment approaches, and key lessons. Sustainability Science, 2(2), 265-275. doi:10.1007/s11625-007-0032-y

Fyall, A., \& Jago, L. (2010). Sustainability in sport \& tourism. Journal of Sport \& Tourism, 14(2-3), 77-81.

Gagnon Thomson, S.C., \& Barton, M.A. (1994). Ecocentric and anthropocentric attitudes toward the environment. Journal of Environmental Psychology, 14, 149-157.

Geeraert, A. (2018). A little green: The European Union's efforts to promote environmental sustainability in sport. In B.P. McCullough \& T.B. Kellison (Eds.), Routledge handbook of sport and the environment (pp. 393-403). London, UK: Routledge.

Gibson, F., Lloyd, J., Bain, S., \& Hottel, D. (2008). Green design and sustainability in sport and recreation facilities. The SMART Journal, 4(2), 26-33.

Gillentine, A. (2018). Sustainable behaviors and the tailgater. In B.P. McCullough \& T.B. Kellison (Eds.), Routledge handbook of sport and the environment (pp. 278-290). London, UK: Routledge.

Goldsmith, E. (1972). A blueprint for survival. Boston, MA: Houghton Mifflin.

Greenhalgh, G., LeCrom, C.W., \& Dwyer, B. (2015). Going green? The behavioral impact of a sport and the environment course. Journal of Contemporary Athletics, 9(1), 49-59.

Griessler, E., \& Littig, B. (2005). Social sustainability: A catchword between political pragmatism and social theory. International Journal for Sustainable Development, 8(1/2), 65-79. doi:10.1504/IJSD. 2005.007375

Grinstead, T.S. (2018). Geoscience and sustainability-In between keywords and buzzwords. Geoforum, 91, 57-60.
Griskevicius, V., Tybur, J.M., \& Van deb Burgh, B. (2010). Going green to be seen: Status, reputation, and conspicuous conservation. Journal of Personality and Social Psychology, 98(3), 392-404. PubMed ID: 20175620 doi: $10.1037 / \mathrm{a} 0017346$

Guha, R., \& Allier, J.M. (2013). Varieties of environmentalism: Essays north and south. London, UK: Routledge.

Haq, G., \& Paul, A. (2012). Environmentalism since 1945. London, UK: Routledge.

Hinchman, L.P., \& Hinchman, S.K. (2007). What we owe the romantics. Environmental Values, 16(3), 333-354. doi:10.3197/ $096327107 X 228382$

Inoue, Y., \& Kent, A. (2012a). Investigating the role of corporate credibility in corporate social marketing: A case study of environmental initiatives by professional sport organizations. Sport Management Review, 15(3), 330-344. doi:10.1016/j.smr.2011.12.002

Inoue, Y., \& Kent, A. (2012b). Sport teams as promoters of proenvironmental behavior: An empirical study. Journal of Sport Management, 26(5), 417-432. doi:10.1123/jsm.26.5.417

Kellison, T.B. (2015). Building sport's green houses: Issues in sustainable facility management. In J. Casper \& M.E. Pfahl (Eds.), Sport management and the natural environment: Theory and practice (pp. 218-237). New York, NY: Routledge.

Kellison, T.B., Bunds, K.S., Casper, J.M., \& Newman, J.I. (2017). Public park usage near hydraulic fracturing operations. Journal of Outdoor Recreation and Tourism, 18, 75-80. doi:10.1016/j.jort. 2017.02.006

Kellison, T.B., \& Casper, J.M. (2017). Environmental legacy of mega sport events. In I. Brittain, J. Bocarro, T. Byers, \& K. Swart (Eds.), Legacies and mega events: Fact or fairy tales (pp. 445-455). London, UK: Routledge.

Kellison, T.B., \& Hong, S. (2015). The adoption and diffusion of pro-environmental stadium design. European Sport Management Quarterly, 15(2), 249-269. doi:10.1080/16184742.2014.995690

Kellison, T.B., \& Kim, Y.K. (2014). Marketing pro-environmental venues in professional sport: Planting seeds of change among existing and prospective consumers. Journal of Sport Management, 28(1), 34-48. doi:10.1123/jsm.2011-0127

Kellison, T.B., \& McCullough, B.P. (2016). A forecast for the mainstreaming of environmental sustainability. Sport \& Entertainment Review, 2(1), 11-18.

Kellison, T.B., \& McCullough, B.P. (2018). A pragmatic perspective on the future of sustainability in sport. In B.P. McCullough \& T.B. Kellison (Eds.), Routledge handbook of sport and the environment (pp. 445-455). London, UK: Routledge.

Kellison, T.B., \& Mondello, M.J. (2012). Organisational perception management in sport: The use of corporate pro-environmental behaviour for desired facility referenda outcomes. Sport Management Review, 15(4), 500-512. doi:10.1016/j.smr.2012.01.005

Kellison, T.B., Trendafilova, S., \& McCullough, B.P. (2015). Considering the social impact of sustainable stadium design. International Journal of Event Management Research, 10(1), 63-83.

Kim, K.-Y., \& Chung, H. (2018). Eco-modernist environmental politics and counter-activism around the 2018 PyeongChang Winter Games. Sociology of Sport Journal, 35(1), 17-28. doi:10.1123/ssj. 2017-0094

Kirby, S.L., Demers, G., \& Parent, S. (2008). Vulnerability/prevention: Considering the needs of disabled and gay athletes in the context of sexual harassment and abuse. International Journal of Sport and Exercise Psychology, 6(4), 407-426. doi:10.1080/1612197X.2008. 9671882

Lee, T.M., Markowitz, E.M., Howe, P.D., Yo, C.Y., \& Leiserowitz, A.A. (2015). Predictors of public climate change awareness and 
risk perception around the world. Nature Climate Change, 5(11), 1014-1020. doi:10.1038/nclimate2728

Lee, W., \& Cunningham, G.B. (2019). Moving toward understanding social justice in sport organizations: A study of engagement in social justice advocacy in sport organizations. Journal of Sport \& Social Issues, 43(3), 245-263. doi:10.1177/0193723519832469

Lemon, A. (2006). Redressing school inequalities in the Eastern Cape, South Africa. Journal of Southern African Studies, 30(2), 269-290. doi:10.1080/0305707042000215392

Lesjø, J.H., \& Gulbrandsen, E.A. (2018). The Olympics: Institutionalization and standardization of sustainability. In B.P. McCullough \& T.B. Kellison (Eds.), Routledge handbook of sport and the environment (pp. 109-120). London, UK: Routledge.

Lindsey, I. (2008). Conceptualising sustainability in sports development. Leisure Studies, 27(3), 279-294. doi:10.1080/ 02614360802048886

Lippi, G., Guidi, G.C., \& Maffulli, N. (2008). Air pollution and sports performance in Beijing. International Journal of Sports Medicine, 29(8), 696-698. doi:10.1055/s-2008-1038684

Locke, S.L. (2019). Estimating the impact of Major League Baseball games on local air pollution. Contemporary Economic Policy, 37(2), 236-244. doi:10.1111/coep.12404

Mallen, C. (2018). Robustness of the sport and environmental sustainability literature and where to go from here. In B.P. McCullough \& T.B. Kellison (Eds.), Routledge handbook of sport and the environment (pp. 11-35). London, UK: Routledge.

Mallen, C., Adams, L., Stevens, J., \& Thompson, L. (2010). Environmental sustainability in sport facility management: A Delphi study. European Sport Management Quarterly, 10(3), 367-389. doi:10. 1080/16184741003774521

Mallen, C., Stevens, J., \& Adams, L.J. (2011). A content analysis of environmental sustainability research in a sport-related journal sample. Journal of Sport Management, 25(3), 240-256. doi:10.1123/jsm. 25.3.240

Martin, N.T., Ross, S.R., \& Irwin, R.L. (2015). Utilizing community-based social marketing in a recycling intervention with tailgaters. Journal of Intercollegiate Sport, 8(1), 57-81. doi:10.1123/jis.2014-0128

McCright, A.M., \& Dunlap, R.E. (2011). The politicization of climate change and polarization in the American public's views of global warming, 2001-2010. The Sociological Quarterly, 52(2), 155-194. doi:10.1111/j.1533-8525.2011.01198.x

McCullough, B.P. (2013). Identifying the influences on sport spectator recycling behaviours using the theory of planned behaviour. International Journal of Sport Management and Marketing, 14(1-4), 146-168. doi:10.1504/IJSMM.2013.060631

McCullough, B.P., \& Cunningham, G.B. (2010). A conceptual model to understand the impetus to engage in and the expected organizational outcomes of green initiatives. Quest, 62(4), 348-363. doi:10.1080/ 00336297.2010.10483654

McCullough, B.P., \& Cunningham, G.B. (2011). Recycling intentions among youth baseball spectators. International Journal of Sport Management and Marketing, 10(1/2), 104-120. doi:10.1504/ IJSMM.2011.043618

McCullough, B.P., \& Kellison, T.B. (2016). Go green for the home team: Sense of place and environmental sustainability in sport. Journal of Sustainability Education, 11(2), 1-14.

McCullough, B.P., \& Kellison, T.B. (Eds.). (2018). Routledge handbook of sport and the environment. New York, UK: Routledge.

McCullough, B.P., \& Kellison, T. (in press). Making our footprint: Constraints in the legitimization of sport ecology in practice and the academy. In B. Wilson \& B. Millington (Eds.), Sport and the environment: Politics and preferred futures. London: Springer.
McCullough, B.P., Kellison, T., \& Wendling, E. (2018). Formation and function of a collegiate athletics sustainability committee. Journal of Amateur Sport, 4(1), 52-81. doi:10.17161/jas.v4i1.6661

McCullough, B.P., Orr, M., \& Watanabe, N. (in press). Measuring externalities: The imperative next step to sustainability assessment in sport. Journal of Sport Management, 1-10. doi:10.1123/jsm.2019-0254

McCullough, B.P., Pfahl, M.E., \& Nguyen, S.N. (2016). The green waves of environmental sustainability in sport. Sport in Society, 19(7), 1040-1065. doi:10.1080/17430437.2015.1096251

Mcincyte, D., Casper, M.J., \& Cole, C.L. (2009). Sports, environmentalism, land use, and urban development. Journal of Sport \& Social Issues, 33(2), 103-110.

McKenzie, T.L., Moody, J.S., Carlson, J.A., Lopez, N.V., \& Elder, J.P. (2013). Neighborhood income matters: Disparities in community recreation facilities, amenities, and programs. Journal of Park and Recreation Administration, 31(4), 12-22. PubMed ID: 25006598

McLeod, C.M., \& Holden, J.T. (2017). Ecological economics and sport stadium public financing. William and Mary Environmental Law and Policy Review, 41(3), 581-603.

McLeod, C.M., \& Holden, J.T. (2018). Steady-state economics and stadiums: Using the date of ecological maturity to conceptualize and govern sport facility construction. In B.P. McCullough \& T.B. Kellison (Eds.), Routledge handbook of sport and the environment (pp. 429-442). New York, NY: Routledge.

Mercado, H.U., \& Grady, J. (2017). Teaching environmental sustainability across the sport management curriculum. Sport Management Education Journal, 11(2), 120-127. doi:10.1123/smej.2016-0018

Moeschberger, S.L., Ordonez, A., Shankar, J., \& Raney, S. (2006). Moving from contact to change. In R.L. Toporek, L.H. Gerstein, N.A. Fouad, G. Roysircar, \& T. Israel (Eds.), Handbook for social justice in counseling psychology: Leadership, vision, and action (pp. 472-486). Thousand Oaks, CA: Sage.

Monz, C.A., Pickering, C.M., \& Hadwen, W.L. (2013). Recent advances in recreation ecology and the implications of different relationships between recreation use and ecological impacts. Frontiers in Ecology and the Environment, 11(8), 441-446. doi:10.1890/120358

National Hockey League. (2014). 2014 NHL Sustainability Report. Retrieved from http://ice.nhl.com/green/report/

Odum, E.P., \& Barrett, G.W. (1971). Fundamentals of ecology. Stamford, CT: Brooks Cole.

Orr, M., \& Inoue, Y. (2019). Sport versus climate: Introducing the climate vulnerability of sport organizations framework. Sport Management Review, 22(4), 452-463. doi:10.1016/j.smr.2018.09.007

Orr, M., \& Schneider, I. (2018). Substitution interests among active-sport tourists: The case of a cross-country ski event. Journal of Sport \& Tourism, 22(4), 315-332. doi:10.1080/14775085.2018.1545600

Pepper, D. (1999). Modern environmentalism: An introduction. London, UK: Routledge.

Pfahl, M. (2011). Sport and the natural environment: A strategic guide. Dubuque, IA: Kendall Hunt Publishing.

Pfahl, M., Casper, J., Trendafilova, S., McCullough, B.P., \& Nguyen, S.N. (2015). Crossing boundaries: An examination of sustainability department and athletics department collaboration regarding environmental issues. Communication and Sport, 3(1), 27-56. doi:10.1177/ 2167479513519253

Phillips, P., \& Turner, P. (2014). Water management in sport. Sport Management Review, 17(3), 376-389. doi:10.1016/j.smr.2013.08.002

Porteshawver, A. (2010). Under review: Stadium construction and state environmental policy acts. Marquette Sports Law Review, 21(1), 339-360.

Porteshawver, A. (2018). Going green: Environmental review, design, and operation of sports facilities. In B.P. McCullough \& T.B. Kellison 
(Eds.), Routledge handbook of sport and the environment (pp. 379392). New York, NY: Routledge.

Quinn, B. (2013). Key concepts in event management. London, UK: Sage. Rigolon, A., \& Flohr, T.L. (2014). Access to parks for youth as an environmental justice issue: Access inequalities and possible solutions. Buildings, 4(2), 69-94. doi:10.3390/buildings4020069

Rootes, C. (2014). Environmental movements: Local, national and global. London, UK: Routledge.

Ross, W.J., \& Leopkey, B. (2017). The adoption and evolution of environmental practices in the Olympic Games. Managing Sport and Leisure, 22(1), 1-18. doi:10.1080/23750472.2017.1326291

Sam, M.P., \& Macris, L.I. (2014). Performance regimes in sport policy: Exploring consequences, vulnerabilities and politics. International Journal of Sport Policy and Politics, 6(3), 513-532. doi:10.1080/ 19406940.2013.851103

Sartore-Baldwin, M.L., \& McCullough, B.P. (2018). Equity-based sustainability and ecocentric management: Creating more ecologically just sport organization practices. Sport Management Review, 21(4), 391-402. doi:10.1016/j.smr.2017.08.009

Sartore-Baldwin, M.L., McCullough, B.P., \& Quatman-Yates, C. (2017). Shared responsibility and issues of injustice and harm within sport. Quest, 69(3), 366-383. doi:10.1080/00336297.2016.1238769

Savery, J., \& Gilbert, K. (2011). Sustainability and sport. Champaign, IL: Common Ground.

Schmuck, D., Matthes, J., \& Naderer, B. (2018). Misleading consumers with green advertising? An affect-reason-involvement account of greenwashing effects in environmental advertising. Journal of Advertising, 47(2), 127-145. doi:10.1080/00913367.2018.1452652

Schubring, A., \& Thiel, A. (2014). Growth problems in youth elite sports: Social conditions, athletes' experiences and sustainability consequences. Reflective Practice, 15(1), 78-91. doi:10.1080/14623943. 2013.868793

Sengupta, S. (2019, September 20). Protesting climate change, young people take to the streets in a global strike. New York Times. Retrieved from https://www.nytimes.com/2019/09/20/climate/global-climate-strike.html

Shaikin, B. (2016, August 31). Angels challenge Anaheim on proposed development next to Angel Stadium. Los Angeles Times. Retrieved from http://www.latimes.com/sports/angels/la-sp-anaheim-angelsstadium-20160831-snap-story.html

Sloane, P.J. (2006). Rottenberg and the economics of sport after 50 years: An evaluation. IZA Discussion Paper No. 2175. Retrieved from https://ssrn.com/abstract $=918719$

Smith, A. (2009). Theorising the relationship between major sport events and social sustainability. Journal of Sport \& Tourism, 14(2-3), 109120. doi:10.1080/14775080902965033

Stocker, T.F., Clarke, G.K.C., Le Treut, H., Lindzen, R.S., Meleshko, V.P., Mugara, R.K., . . , Wild, M. (2001). Physical climate processes and feedbacks. In IPCC, 2001: Climate change 2001: The scientific basis. Contribution of working group I to the third assessment report of the intergovernmental panel on climate change (pp. 417-470). Cambridge, UK: Cambridge University Press.

Svensson, P.G. (2017). Organizational hybridity: A conceptualization of how sport for development and peace organizations respond to divergent institutional demands. Sport Management Review, 20(5), 443-454. doi:10.1016/j.smr.2017.03.004

Sze, J. (2009). Sports and environmental justice: "Games" of race, place, nostalgia, and power in neoliberal New York City. Journal of Sport \& Social Issues, 33(2), 111-129. doi:10.1177/ 0193723509332581
Sze, J., \& London, J.K. (2008). Environmental justice at the crossroads. Sociology Compass, 2(4), 1331-1354. doi:10.1111/j.1751-9020. 2008.00131.x

Taks, M. (2013). Social sustainability of non-mega sport events in a global world. European Journal for Sport and Society, 10(2), 121-141. doi:10.1080/16138171.2013.11687915

Trail, G.T. (2016). Marketing sustainability through sport. Seattle, WA: Sport Consumer Research Consultants LLC.

Trail, G.T., \& McCullough, B.P. (2018). Marketing sustainability through sport: The importance of target market insights. In B.P. McCullough \& T.B. Kellison (Eds.), Routledge handbook of sport and the environment (pp. 134-148). London, UK: Routledge.

Trail, G.T., \& McCullough, B.P. (in press). Marketing sustainability through sport: Testing the sport participant sustainability behavior model. European Sport Management Quarterly, 1-35. doi:10.1080/ 16184742.2019 .1580301

Trendafilova, S., Kellison, T.B., \& Spearman, L. (2014). Environmental sustainability in sport facilities in East Tennessee. Journal of Facility Planning, Design, and Management, 2(1), 1-10.

Trendafilova, S., McCullough, B., Pfahl, M., Nguyen, S.N., Casper, J., \& Picariello, M. (2014). Environmental sustainability in sport: Current state and future trends. Global Journal on Advances Pure and Applied Sciences, 3, 9-14.

Trendafilova, S., \& McCullough, B.P. (2018). Environmental sustainability scholarship and the efforts of the sport sector: A rapid review of literature. Cogent Social Sciences, 4(1), 1-15. doi:10.1080/ 23311886.2018.1467256

Triantafyllidis, S., Ries, R.J., \& Kaplanidou, K. (2018). Carbon dioxide emissions of spectators' transportation in collegiate sporting events: Comparing on-campus and off-campus stadium locations. Sustainability, 10(241), 1-18.

United Nations Framework Convention on Climate Change. (2017, November 5). Sports representatives and the UN pitch for climate action [Press release]. Retrieved from https://cop23.unfccc.int/news/ sports-representatives-and-the-un-pitch-for-climate-action

Van Lange, P.A.M., Joireman, J., \& Milinski, M. (2018). Climate change: What psychology can offer in terms of insights and solutions. Current Directions in Psychological Science, 27(4), 269-274. PubMed ID: 30166778 doi:10.1177/0963721417753945

Wallace, C. (2012). Framing the Cape Town World Cup stadium in the media: The politics of identity and sports in South Africa. Journal of African Media Studies, 4(3), 315-329. doi:10.1386/jams.4.3. 315_1

Watanabe, N.M., Yan, G., Soebbing, B.P., \& Fu, W. (2019). Air pollution and attendance in the Chinese Super League: Environmental economics and the demand for sport. Journal of Sport Management, 33(4), 1-14. doi:10.1123/jsm.2018-0214

Wicker, P. (2018). The carbon footprint of active sport tourists: An empirical analysis of skiers and boarders. Journal of Sport \& Tourism, 22(2), 151-171. doi:10.1080/14775085.2017. 1313706

Wicker, P. (2019). The carbon footprint of active sport participants. Sport Management Review, 22(4), 513-526.

Wolf, J., \& Moser, S.C. (2011). Individual understandings, perceptions, and engagement with climate change: Insights from in-depth studies across the world. Interdisciplinary Reviews of Climate Change, 2(4), 547-569. doi:10.1002/wcc. 120

World Commission on Environment and Development. (1987). Our common future. Oxford, UK: Oxford University Press. 